The International Association for the Prevention of Blindness met on April 5. Everyone regretted the unavoidable absence of Professor de Lapersonne; his presidential report was read by Professor Terrien. The scientific meeting was held the same day under the presidency of Dr. Park Lewis (U.S.A.). Professor van Duyse (Belgium) gave a résumé of an important paper on "Classification of the causes of Blindness" which was followed by short papers by Mr. Paton (Great Britain), Mr. MacCallan (Great Britain), Professor Marquez (Spain) and Mr. Bickerton (Great Britain). Professor Francheschetti (Switzerland) then read at full length a paper on "Hereditary Diseases of the Eyes."

It is proposed to hold a joint meeting of the two societies in Paris at the time of the annual congress of the Société française d'Ophtalmologie in May 1936. The subject for discussion will be "The treatment of trachoma : (a) when carried out by an ophthalmologist ; $(b)$ when carried out by a general practitioner."

Among the festivities arranged in honour of the foreign visitors there was a splendid entertainment given at Clothworkers' Hall by the Master and Wardens on April 3. They were the guests of the Council of the Ophthalmological Society at the Annual Dinner on April 4, and of Sir John Parsons and Mr. and Mrs. Leslie Paton at dinner on April 5, previous to attending a reception at Lancaster House given by His Majesty's Government.

\title{
INTERNATIONAL ASSOCIATION FOR THE PREVENTION OF BLINDNESS
}

The annual General Assembly of the International Association for the Prevention of Blindness was held on Friday, April 5, by the courtesy of the Royal Society of Medicine in the House of the Society.

The Executive Committee met in the morning. Dr. Park Lewis, of Buffalo, U.S.A., presided in the regrettable absence of Professor de Lapersonne, of Paris. The Report for the year was presented in French by Professor Terrien, and in English by Mr. Bishop Harman. The accounts showed an increase of contributions from French sources. An appropriation of 3,000 francs was voted for propaganda purposes in the formation of sight-saving classes in France. Professor van Duyse of Ghent was elected secretary-general, and Mr. MacCallan to represent Great Britain in place of $\mathrm{Mr}$. Cridland, whose early death was deplored. A joint meeting was arranged between the Association and the Organization against Trachoma to be held in Paris in 1936. The subject 
for the first report is to be "Epidemic conjuctivitis in children from birth to ten years of age," prepared by Mr. Bishop Harman.

The afternoon was devoted to a public meeting at which there was a large attendance. Professor van Duyse presented a report on "The Classification of the Causes of Blindness." He agreed with Trousseau that "without an accurate knowledge of the causes it is impossible to discover the diseases against which we must concentrate our efforts." His committee showed two opposed views as to the character of such a classification. Professor Marquez (Spain) and Dr. Marx (Holland) desired most detailed classifications which would serve as a basis for scientific discussion. Mr. Bishop Harman and Dr. Maziny Bey (Egypt) desired a briefer classification, more simple, more clear, more adaptable, which would be used to draw the attention of the authorities to the economic losses resulting from blindness. Professor van Duyse reported that the case for each of these classifications was made out, and each was needed for its special purposes.

Mr. Leslie Paton, speaking as a member of the Prevention of Blindness Committee of England said that their investigation of actual reports of cases of blindness made on a lengthy classification was well advanced and he hoped that the findings would be published shortly. So far as they had gone he was inclined to think that experience showed that some shortening of their classification might be advantageous.

Mr. Myles Bickerton (London) said that the tale of the blind for this country was lamentably deficient. Their means of finding out the numbers with accuracy was unsatisfactory. Mr. Lovett of the Ministry of Health (also a member of the Prevention of Blindness Committee) said that there was ground for thinking that Mr. Bickerton's criticisms were not wholly justified. It was true that well-to-do blind folk did not apply for blind pensions, but they had no hesitation in claiming free wireless licences, so that their numbers were known. So far as other classes were concerned the social services of the country were most complete.

Professor A. Franceschetti, of Geneva, presented a report on Hereditary Disease of the Eye resulting in Blindness, their social consequences and the measures that may be proposed. The report had been translated into English and those attending the assembly had the advantage of heing able to follow the argument of this excellent report in detail.

\section{Reception at Lancaster House}

On the evening of Friday, April 6, there was a great reception by the Government at Lancaster House, adjoining St. James' Palace. The company was received by Mr. Geoffrey Shakespeare, 
M.P., Parliamentary Secretary to the Ministry of Health and Mrs. Shakespeare, in the regrettable absence, through illness, of the Right Hon. Sir Hilton Young, the Minister of Health. A great company, estimated to have exceeded one thousand assembled in this beautiful Georgian house, truly one of the lesser palaces of London. No more fitting place could have been found for such a reception, the setting was magnificent, the music delightful, and the priceless collection of the London Museum which was open to the company gave an additional interest to the reception; whilst the elegance of the dresses of the ladies lent an added colour to the proceedings. It was perhaps regrettable that the men had not been ordered to appear in academic dress, then the effect would have been brilliant! The delegates from abroad, and some thirty-four countries were represented, were high in their appreciation of the Government hospitality. Many members of the Ophthalmological Society, of the International Ophthalmological Council, the Organization for the Prevention of Blindness were present. It is interesting to note that $\mathrm{Mr}$. Percy Flemming, sometime ophthalmic surgeon at University College Hospital, is now associated with the work of the London Museum.

\section{THE MOORFIELDS EYE HOSPITAL}

Opening of the King George V Extension by their Royal Highnesses the Duke and Duchess of York, May 16, 1935

At the opening of the King George $\mathrm{V}$ extension of the Royal London Ophthalmic Hospital (Moorfields) their Royal Highnesses the Duke and Duchess of York were welcomed on arrival in the Borough by His Worship the Mayor of Finsbury and the Mayoress, and at the Hospital by Theodore W. Luling, Esq., Chairman of the Hospital, and Mrs. Luling. H.R.H. Prince Arthur of Connaught, K.G., President of the Hospital, was regrettably absent owing to illness.

Mr. Luling welcomed their Royal Highnesses at the opening ceremony and spoke of the interest that members of the Royal Family had always shown in the work of the Hospital. Queen Victoria was associated with the old hospital for many years. King Edward and Queen Alexandra, when Prince and Princess of Wales, laid the foundation stone of the present hospital, and the present King and Queen, when Duke and Duchess of York, declared the building open in 1899 .

The extension, he said, had been necessary to accommodate and 